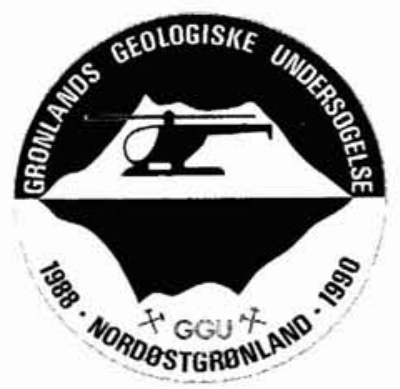

\title{
Lead isotope signatures of mineralised rocks in the Caledonian fold belt of North-East Greenland
}

\author{
Sven Monrad Jensen
}

\begin{abstract}
Lead isotope analyses of samples with small accumulations of metals and incompatible elements from the Precambrian gneisses of North-East Greenland indicate that mineralisation mostly involved remobilisation of metals from local host rocks. Source ages of lead fall in three groups: (1) 1700-2400 Ma for Lower Proterozoic skarns, Caledonian sulphide-bearing pegmatites and quartz veins, and post-Jurassic pyrite-mineralised fault breccias; (2) 900-1000 Ma for Caledonian shear zones and Caledonian(?) skarns in Middle-Late Proterozoic rocks; and (3) $\sim 400 \mathrm{Ma}$ for Caledonian thrust zones with associated relative uranium enrichment along thrust planes.
\end{abstract}

S. M. J., Department of Geology, University of Aarhus, DK-8000 Århus C, Denmark. Present address: Geological Survey of Greenland, Øster Voldgade 10, DK-1350 Copenhagen K, Denmark.

In the Caledonian fold belt of North-East Greenland $\left(76^{\circ}-78^{\circ} \mathrm{N}\right)$ only brief reconnaissance for indications of economic mineralisation has been carried out. Showings of mineralised rocks include skarn, shear and thrust zones with disseminated pyrite or hematite, and pyrite-mineralised fault breccias (Jensen \& Stendal, 1994). None of the showings have dimensions or element concentrations of economic significance, but the study of their lead isotope systematics contributes to a characterisation of crustal source rocks of lead in this segment of the Caledonian fold belt. The lead isotope patterns also form a basis for comparison with lead isotope data for economic mineralisation in central East Greenland (Jensen, 1993). The area of study in North-East Greenland (Fig. 1) is dominated by Precambrian crystalline rocks which have been reworked during the Caledonian orogeny. The studied showings of mineralised rocks may be grouped by age and genetic association: (1) Lower Proterozoic skarns developed along contacts between paragneisses and orthogneisses; (2) Caledonian thrust and shear zones in the Precambrian metamorphic basement; (3) post-Jurassic normal faults with associated pyrite-mineralised breccias. The geology and geochemical characteristics of the mineralised localities are described by Jensen \& Stendal (1994); in the present paper lead isotope data are presented and discussed.

\section{Analytical procedure and precision}

The isotopic compositions of lead in sixty mineral samples from mineralised rocks have been determined.
Samples of sulphide minerals and uraninite were dissolved in nitric acid, iron oxides in hydrochloric acid, and other minerals and a few whole rock samples in hydrofluoric acid. Lead was then extracted in ion exchange columns from a hydrobromic acid solution and eluted with hydrochloric acid. The samples were loaded with silica gel in dilute phosphoric acid on single rhenium filaments and ionised at $1230^{\circ} \mathrm{C}$ in a Finnigan MAT-261 multiple-collector mass spectrometer. The NBS SRM 981 lead standard was measured frequently and average isotope ratios of 50 measurements were compared to the 'true' values of Todt et al. (1984). The determined mass fractionation factors for the ratios ${ }^{206} \mathrm{~Pb} /{ }^{204} \mathrm{~Pb},{ }^{207} \mathrm{~Pb} /{ }^{204} \mathrm{~Pb}$ and ${ }^{208} \mathrm{~Pb} /{ }^{204} \mathrm{~Pb}$ are $1.0025,1.0037$ and 1.0050 , respectively. The total errors for the measured lead isotope ratios are judged to be well below $0.10 \%$. All confidence intervals stated in this paper are $2 \sigma$.

Isochrons were calculated using the York (1969) procedure for straight line fitting of bivariate data with correlated errors. The minimised quantity MSWD (mean square of weighted deviates) provides a measure of the fit. The present-day ${ }^{238} \mathrm{U} /{ }^{235} \mathrm{U}$ ratio and the decay constants for ${ }^{232} \mathrm{Th},{ }^{235} \mathrm{U}$ and ${ }^{238} \mathrm{U}$ from Steiger \& Jäger (1977), together with the primordial terrestrial lead composition and the age of the Earth from Tatsumoto $e t$ al. (1973), were used in calculation of ${ }^{207} \mathrm{~Pb} /{ }^{206} \mathrm{~Pb}$ ages and model first-stage $\mu\left({ }^{238} \mathrm{~Pb} /{ }^{204} \mathrm{~Pb}\right)$ values.

\section{Secondary isochrons}

Some principles of geochronological interpretation of 


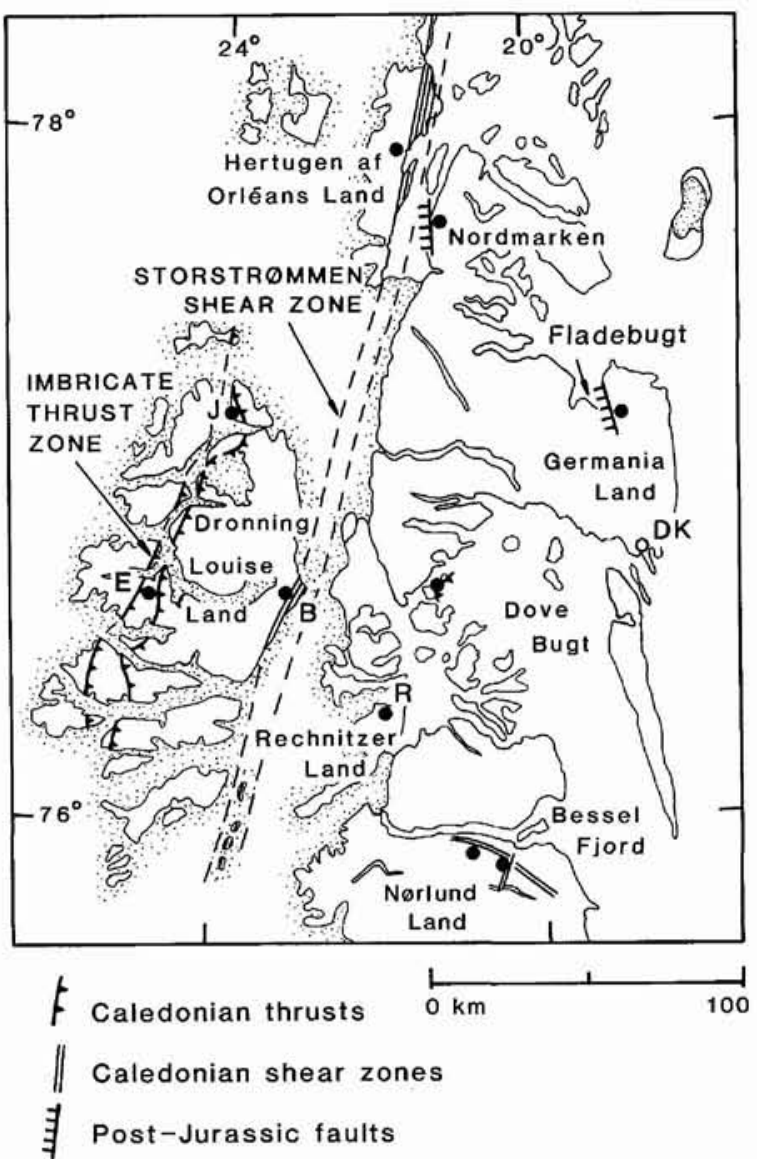

Fig. 1. Map of North-East Greenland $\left(76^{\circ}-78^{\circ} \mathrm{N}\right)$. Filled circles, sample localities for new lead isotope analyses; open circle (DK), locality of Danmarkshavn gneiss sample analysed by Steiger et al. (1976). $\mathrm{R}=$ Ravnedalen; $\mathrm{B}=$ Borgjøkel; $\mathrm{E}=$ Eigil $S \emptyset ; J=H$. A. Jensen Bjerg.

lead isotope data from mineralised rock suites are discussed below. For an extensive review of the decay systematics of the uranium-lead and thorium-lead systems and their geological significance the reader is referred to Kanasewich (1968) and Faure (1986).

Consider that, $T$ years ago, some geological process reworked a segment of the Earth's crust to produce a system that then remained closed to gains or losses of uranium, thorium and lead until a time $t$ years ago; consider further that a geological sample was collected from the system and its new lead isotope composition determined. The continually evolving isotopic ratios of the lead in the system would follow a growth curve in the ${ }^{207} \mathrm{~Pb} /{ }^{204} \mathrm{~Pb}-{ }^{206} \mathrm{~Pb} /{ }^{204} \mathrm{~Pb}$ diagram (curved path from $I$ to $A$; Fig. 2). For a system with a higher $\mu\left({ }^{238} \mathrm{U} /{ }^{204} \mathrm{~Pb}\right)$ value the growth curve would be displaced towards the upper righthand corner of the diagram (e.g. curved path from $I$ to $B$; Fig. 2). The lead in cogenetic rocks or minerals with varying $\mu$ values would evolve along a series of growth curves ending at later times $t$, with compositions lying on straight lines that pass through the initial common composition $(I-d-c-a-b$ for $0<t<T$, or $I-D-C-A-B$ for $t=0$; Fig. 2). Such lines are termed secondary isochrons. The slope $R$ of a secondary isochron is:

$R=\frac{1}{137.88}\left[\frac{e^{\lambda_{2} T}-e^{\lambda_{2} t}}{e^{\lambda_{1} T}-e^{\lambda_{1} t}}\right]$,

[Equation 1]

where $\lambda_{1}$ and $\lambda_{2}$ are the decay constants for ${ }^{238} \mathrm{U}$ and ${ }^{235} \mathrm{U}$, respectively (e.g. Kanasewich, 1968; Faure, 1986). The slope depends on the times $T$ and $t$ only, and interpretation of the isochron requires no knowledge of the history of the lead prior to $T$.

Galena and pyrite, the sulphide minerals most commonly used in lead isotope studies, normally have such low contents of uranium and thorium that radiogenic lead evolution in them is considered to have essentially stopped at the time of mineralisation. Sulphide minerals thus serve as fossil indicators of the evolution of the contained lead prior to mineralisation. When applying Equation 1 to an isochron defined by lead isotope ratios for a sulphide mineral deposit, $T$ is the age of the source rocks for the lead (typically an age of sedimentation, metamorphism or magmatism when lead in the rocks concerned was homogenised), and $t$ is the age of mineralisation when lead was mobilised from the source and sequestered in sulphide minerals. If one of the ages $t$ or $T$ is known from other geological evidence the corresponding age, $T$ or $t$, may be found from Equation 1.

\section{Lead isotope signatures \\ Pre-Caledonian skarns}

Lead isotope data for pre-Caledonian mineralised skarns in Lower to Middle Proterozoic gneisses in Rechnitzer Land and on two small islands in Dove Bugt (Fig. 1) are presented in Table 1. In a ${ }^{207} \mathrm{~Pb} /{ }^{204} \mathrm{~Pb}-{ }^{206} \mathrm{~Pb} / 204 \mathrm{~Pb}$ diagram (Fig. 3) the data points for sulphide samples from Rechnitzer Land define rather poorly a secondary isochron with a slope of $0.11984 \pm 0.02711(n=4$, MSWD $=8.78$ ). Interpretation of the isochron is ambiguous because the nature and degree of Caledonian deformation and metamorphism in the area are not well known. In the most simple model it is assumed that the sulphide minerals in the skarn remained closed systems from the Lower Proterozoic to the present day $(t=0)$. The source age thus obtained from Equation 1 is $1950_{-470}^{+360} \mathrm{Ma}$ and a corresponding first-stage $\mu$ value is 7.84 . This interpretation, however, is not very probable: it requires significant radiogenic evolution of the lead while bound in the sulphide minerals, and it does not accommodate 


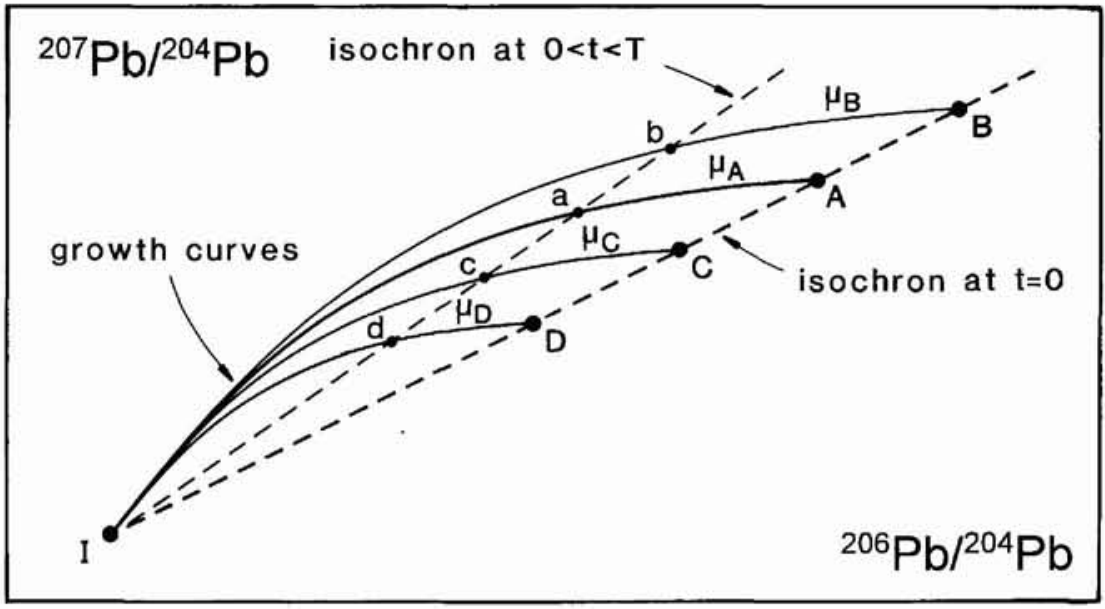

Fig. 2. Schematic ${ }^{207} \mathrm{~Pb} /{ }^{204} \mathrm{~Pb}-{ }^{206} \mathrm{~Pb} /{ }^{204} \mathrm{~Pb}$ diagram illustrating the concept of secondary isochrons. $I$, initial common lead isotope composition at the time $T$ of homogenisation of the system. This lead evolved along a growth curve to the present composition $A$. Lead in samples from a cogenetic suite of rocks with varying $\mu\left({ }^{238} \mathrm{U} /{ }^{204} \mathrm{~Pb}\right)$ values evolved along a series of growth curves ending in points that lie on a straight line: a secondary isochron. For example, the lead in four rocks with the ${ }^{238} \mathrm{U} /{ }^{204} \mathrm{~Pb}$ ratios $\mu_{\mathrm{A}}, \mu_{\mathrm{B}}, \mu_{\mathrm{C}}$ and $\mu_{\mathrm{D}}$ had evolved to $a, b, c$ and $d$ at a time $0<t<T$, and to $A, B, C$ and $D$ at $t=0$.

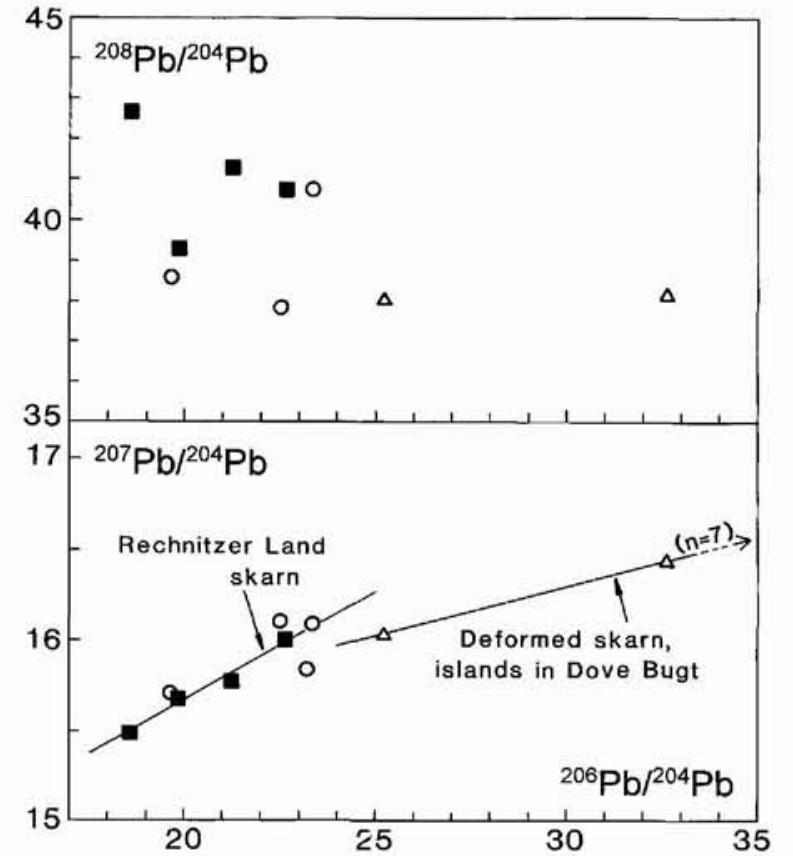

Fig. 3. Lead isotope diagrams for pre-Caledonian skarns. Filled squares, Rechnitzer Land samples define ${ }^{207} \mathrm{~Pb} /{ }^{206} \mathrm{~Pb}$ isochron for formation of Lower Proterozoic skarn; circles, moderately radiogenic samples from the islands in Dove Bugt scatter around the Rechnitzer Land isochron; triangles, mineral separates of sample 365156 from islands in Dove Bugt (of which 5 extremely radiogenic samples are not shown) define isochron for Caledonian deformation of the Lower Proterozoic skarn. Note the lack of correlation in the ${ }^{208} \mathrm{~Pb} /{ }^{004} \mathrm{~Pb}-{ }^{206} \mathrm{~Pb} /{ }^{204} \mathrm{~Pb}$ diagram. possible Caledonian metamorphism and deformation of the skarn. In a perhaps more realistic model the lead in sulphide minerals in the Lower Proterozoic skarn did not evolve further until the skarn was affected by Caledonian metamorphism and deformation. The sulphide minerals

Table 1. Lead isotope analyses for mineralised pre-Caledonian skarns

\begin{tabular}{|c|c|c|c|c|}
\hline Sample* & mineral & $\begin{array}{l}{ }^{206} \mathrm{~Pb} / \\
{ }^{204} \mathrm{~Pb}\end{array}$ & $\begin{array}{l}{ }^{207} \mathrm{~Pb} / \\
{ }^{204} \mathrm{~Pb}\end{array}$ & $\begin{array}{l}{ }^{20 x} \mathrm{~Pb} / \\
{ }^{201} \mathrm{~Pb}\end{array}$ \\
\hline \multicolumn{5}{|c|}{ Ravnedalen, Rechnitzer Land } \\
\hline 139 skarn & py & 21.268 & 15.780 & 41.283 \\
\hline 140 skarn & py & 22.662 & 16.010 & 40.726 \\
\hline 141 pegmatite & py & 19.842 & 15.685 & 39.286 \\
\hline 143 amphibolite & py & 18.589 & 15.494 & 42.677 \\
\hline \multicolumn{5}{|l|}{ Islands in Dove Bugt } \\
\hline 145 hbl skarn & py & 23.221 & 15.841 & 57.961 \\
\hline 147 hbl-gt-mt skarn & py & 19.655 & 15.706 & 38.589 \\
\hline 153 marble skarn & py & 22.526 & 16.103 & 37.834 \\
\hline $158 \mathrm{mt}$-hbl skarn & py & 23.355 & 16.089 & 40.727 \\
\hline 156 calc-sil skam & mug & 25.228 & 16.027 & 38.031 \\
\hline 156 calc-sil skam & nor & 32.626 & 16.433 & 38.149 \\
\hline 156 calc-sil skarn & apy/ura & 134.99 & 22.048 & 53.347 \\
\hline 156 calc-sil skarn & apy/ura & 135.36 & 22.050 & 39.693 \\
\hline 156 calc-sil skam & apy/ura & 1853.2 & 115.94 & 67.935 \\
\hline 156 calc-sil skarn & ura & 76923 & 4217.2 & 1307.8 \\
\hline 156 calc-sil skarn & ura & 64516 & 3532.1 & 1176.2 \\
\hline
\end{tabular}

*GGU sample numbers prefixed 365 .

apy: arsenopyrite; calc-sil: calc-silicate; hbl: hornblende; nor: norbergite; gt: garnet; $\mathrm{mt}$ : magnetite; mug: musgravite; py: pyrite; ura: uraninite. 


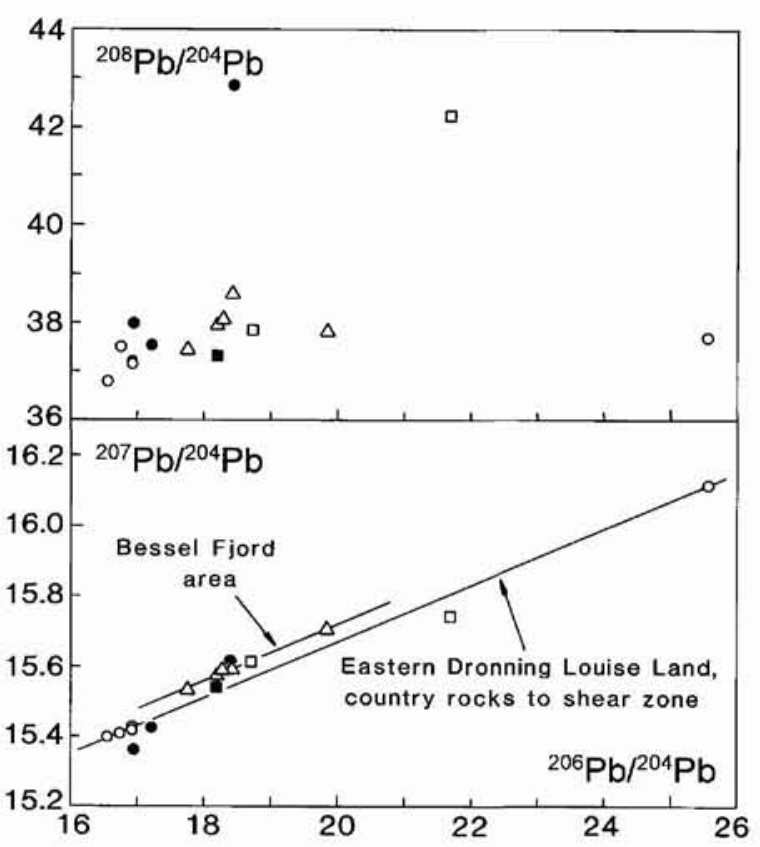

Fig. 4. Lead isotope diagrams for Caledonian shear zones and skarn. Bessel Fjord area: triangles, shear zones and skarn define ${ }^{207} \mathrm{~Pb} /{ }^{206} \mathrm{~Pb}$ isochron for Middle Proterozoic host rocks (Smallefjord sequence). Storstrommen shear zone: open circles, data points for sulphides in country rocks to the shear zone define ${ }^{207} \mathrm{~Pb} /{ }^{206} \mathrm{~Pb}$ isochron for Middle Proterozoic cover sequence (eastern Dronning Louise Land); open squares, country rocks (Hertugen af Orléans Land); filled symbols, mylonitised rocks outline steep array suggesting addition of lead from deeper crustal sources.

may then have recrystallised and equilibrated isotopically with the host rocks, adopting their evolved lead isotope signatures. The lead in the sulphides did not evolve further after the Caledonian orogeny. If an age for Caledonian metamorphism and deformation of $t=400 \mathrm{Ma}$ is assumed, the corresponding source (skarn mineralisation) age $T$ is $1740_{-515}^{+385} \mathrm{Ma}(\mu=7.78)$.

Samples from a skarn on the islands in Dove Bugt follow two contrasting linear trends in the ${ }^{207} \mathrm{~Pb} /{ }^{204} \mathrm{~Pb}-$ ${ }^{206} \mathrm{~Pb} /{ }^{204} \mathrm{~Pb}$ diagram (Fig. 3): moderately radiogenic pyrite samples $(365145,365147,365153,365158)$ scatter around the Rechnitzer Land isochron, whereas seven highly radiogenic mineral separates from sample 365156 define a well-fitted isochron with a distinctly lower slope $(0.05461 \pm 0.00007, \mathrm{MSWD}=0.59)$ that corresponds to a mineralisation age of $396 \pm 3 \mathrm{Ma}$. The radiogenic mineral separates (arsenopyrite, musgravite, norbergite and uraninite) have ${ }^{206} \mathrm{~Pb} /{ }^{04} \mathrm{~Pb}$ ratios ranging from 25.2 to c. 77000 . Musgravite, a rare beryllium-bearing oxide mineral (Chadwick et al., 1990, 1993) is practically insoluble; leaching in hot $\left(150^{\circ} \mathrm{C}\right)$ hydrofluoric acid for one week produced a slight colouring of the acid but hardly any corrosion of the grains. The lead isotope ratios for musgravite thus apply to a uraniferous surface coating on the grains, and the radiogenic nature of the norbergite and arsenopyrite samples is thought to be caused by similar grain surface coatings.

Neither of the two linear trends outlined above can be distinguished in the ${ }^{208} \mathrm{~Pb} /{ }^{204} \mathrm{~Pb}-{ }^{206} \mathrm{~Pb} /{ }^{04} \mathrm{~Pb}$ diagram (Fig. 3). For the Precambrian skarns the lack of correlation between uranogenic and thorogenic lead isotope ratios reflects derivation of the lead in the iron and copper sulphides from local host rock lithologies (paragneiss, amphibolite, pegmatite and calc-silicate skarn) that had different thorium-lead and thorium-uranium ratios. For the extremely radiogenic lead in mineral separates from the islands in Dove Bugt a primarily uranogenic origin is indicated, i.e., the skarn was locally enriched in uranium, but not in thorium. Low $\mathrm{Th} / \mathrm{U}$ ratios are also suggested by two whole-rock chemical analyses of the musgravitebearing skarn ( $3.3 \mathrm{ppm} \mathrm{Th} / 79.5 \mathrm{ppm} \mathrm{U}$, and $3.5 \mathrm{ppm}$ $\mathrm{Th} / 47 \mathrm{ppm} \mathrm{U}$, respectively). In contrast, the moderately radiogenic samples from the islands in Dove Bugt and Rechnitzer Land have whole-rock $\mathrm{Th} / \mathrm{U}$ abundance ratios

\section{Table 2. Lead isotope analyses for sulphide} occurrences in Caledonian shear zones

\begin{tabular}{lllll}
\hline & & $\begin{array}{c}{ }^{206} \mathrm{~Pb} / \\
{ }^{204} \mathrm{~Pb}\end{array}$ & ${ }^{207} \mathrm{~Pb} /$ & ${ }^{204} \mathrm{~Pb}$ \\
\hline Bessel Fjord region & & & & \\
122 diopside skarn & py & 18.228 & 15.578 & 37.944 \\
124 diopside skarn & py & 18.431 & 15.592 & 38.565 \\
127 mylz; qz-gt amph & py & 19.850 & 15.706 & 37.795 \\
130 mylz; pegm in amph & py & 18.297 & 15.590 & 38.051 \\
131 mylz; vein in amph & py & 17.760 & 15.534 & 37.431
\end{tabular}

Storstrømmen shear zone

Borgjokel, eastern Dronning Louise Land

$\begin{array}{lllll}014 \text { c-r; gt amph } & \text { py } & 16.558 & 15.399 & 36.790 \\ 015 \text { c-r; amph } & \text { py } & 16.932 & 15.425 & 37.169 \\ 015 \text { c-r; amph } & \text { py } & 16.931 & 15.418 & 37.150 \\ 016 \text { c-r; amph } & \text { py } & 16.749 & 15.408 & 37.505 \\ 023 \text { c-r; qz-gt-hbl skarn } & \text { po } & 25.554 & 16.117 & 37.694 \\ 017 \text { mylz; amph } & \text { wr } & 17.224 & 15.427 & 37.533 \\ 018 \text { mylz; amph } & \text { wr } & 18.430 & 15.599 & 42.850 \\ \text { 020 mylz; amph/gneiss } & \text { po } & 16.946 & 15.362 & 37.981 \\ & & & & \\ \text { Hertugen af Orléans Land } & & & & \\ \text { 065 c-r; qz vein in amph } & \text { py } & 18.723 & 15.616 & 37.849 \\ \text { 070 c-r; amph } & \text { py } & 21.685 & 15.742 & 42.255 \\ \text { 068 c-r; amph } & \text { py } & 18.203 & 15.546 & 37.304\end{array}$

*GGU sample numbers prefixed 365 .

amph: amphibolite; c-r: country rocks to Storstrømmen shear zone; gt: garnet; hbl: hornblende; mylz: mylonite zone; pegm: pegmatite; po: pyrrhotite; py: pyrite; qz: quartz; wr: whole-rock. 
between 0.7 and 10 ( 8 ratios with a median value of 1.2). The high ratio of 10 applies to sample 365145 whose ${ }^{208} \mathrm{~Pb} /{ }^{204} \mathrm{~Pb}$ ratio in pyrite is abnormally high $(57.961$; not shown in Fig. 3).

The skarns appear to have formed when granitic magmas intruded the supracrustal rocks in the Early Proterozoic 1700-2000 Ma ago. During the Caledonian orogeny, about $400 \mathrm{Ma}$ ago, the skarn on the islands in Dove Bugt was deformed and metamorphic fluids migrated along the shear planes and modified the skarn; uranium was incorporated in uraninite and in intergranular mineral coatings and uranogenic lead began to accumulate. The skarn in Rechnitzer Land may also have been affected by Caledonian metamorphism and deformation, whereby the sulphide minerals recrystallised and acquired the evolved lead isotope composition of the host rocks.

\section{Caledonian shear zones}

Isotopic analyses of lead in pyrite disseminations from the Storstrømmen shear zone and Caledonian shear zones and skarn in the Bessel Fjord region are listed in Table 2.

Five pyrite samples from Caledonian shear zones and Caledonian(?) skarns in the Middle Proterozoic Smallefjord supracrustal sequence south of Bessel Fjord (Fig. 1) form a well-defined secondary isochron with a slope of $0.08081 \pm 0.00709(n=5$, MSWD $=0.15)$ in the ${ }^{207} \mathrm{~Pb} /$ ${ }^{204} \mathrm{~Pb}-{ }^{206} \mathrm{~Pb} /{ }^{204} \mathrm{~Pb}$ diagram (Fig. 4). Using a Caledonian (400 Ma) sulphide mineralisation age in Equation 1 gives a corresponding lead source age of $930_{-205}^{+180} \mathrm{Ma}(\mu=8.08)$, implying that the lead mobilised in both shear zones and skarns was derived from the local Middle Proterozoic host rocks.

Iron sulphide-mineralised rocks from areas around the Storstrømmen shear zone in eastern Dronning Louise Land and Hertugen af Orléans Land (Fig. 1) show a wide range of lead isotope ratios. In the ${ }^{207} \mathrm{~Pb} /{ }^{204} \mathrm{~Pb}-{ }^{206} \mathrm{~Pb} /{ }^{204} \mathrm{~Pb}$ diagram (Fig. 4) the data points lie on a broad linear trend parallel to the Bessel Fjord isochron, but with considerably more scatter. Samples of country rocks to the Storstrømmen shear zone in eastern Dronning Louise Land define a secondary isochron $(0.08037 \pm 0.00132$, $n=5$, MSWD $=1.28$ ) that, when assuming a Caledonian sulphide mineralisation age of $400 \mathrm{Ma}$, corresponds to a lead source age of $915 \pm 35 \mathrm{Ma}(\mu=8.00)$. The precision of this age is achieved because of the large spread in isotope ratios caused by the radiogenic lead in sample 365023. Two pyrite-mineralised samples from similar country rocks to the Storstrømmen shear zone in Hertugen af Orléans Land broadly follow the latter trend (Fig. 4). Four mylonitised samples from the Storstrømmen shear zone appear to outline a steeper array that projects to lower ${ }^{207} \mathrm{~Pb} /{ }^{204} \mathrm{~Pb}$ lead compositions and possibly an older and deeper crustal source.

In the ${ }^{208} \mathrm{~Pb} /{ }^{204} \mathrm{~Pb}-{ }^{206} \mathrm{~Pb} /{ }^{204} \mathrm{~Pb}$ diagram (Fig. 4), disregarding radiogenic samples with ${ }^{206} \mathrm{~Pb} /{ }^{04} \mathrm{~Pb}$ ratios over 19 , samples from the Storstrømmen shear zone and the Bessel Fjord region outline separate compositional fields that point to different thorium-uranium ratios in the source rocks. The first-stage $\mu$ values for lead evolution in the two regions are also slightly different: 8.1 for the Bessel Fjord rocks and 8.0 for country rocks to the Storstrømmen shear zone in eastern Dronning Louise Land.

\section{The imbricate thrust zone of Dronning Louise Land}

Lead isotope data for mineral showings within the Caledonian imbricate thrust zone of Dronning Louise Land are listed in Table 3. Two linear arrays with distinctly different slopes are outlined in the ${ }^{207} \mathrm{~Pb} /{ }^{204} \mathrm{~Pb}$ ${ }^{206} \mathrm{~Pb} /{ }^{204} \mathrm{~Pb}$ diagram (Fig. 5). In coordinates of ${ }^{208} \mathrm{~Pb} /{ }^{204} \mathrm{~Pb}$ versus ${ }^{206} \mathrm{~Pb} /{ }^{204} \mathrm{~Pb}$ data points for pyrite-mineralised pegmatites and quartz veins lie on steep, thorogenic trends, and points for hematised fossil magnetite placers and hematised amphibolites show a more diffuse, uranogenic trend. The lead in the hematised rocks is radiogenic with ${ }^{206} \mathrm{~Pb} /{ }^{204} \mathrm{~Pb}$ ratios in the range $17.2-40.0$, and defines a ${ }^{207} \mathrm{~Pb} /{ }^{206} \mathrm{~Pb}$ isochron roughly parallel to that determined for the Caledonian shear zone on the islands in Dove Bugt (Fig. 3); the isochron has a slope of $0.05554 \pm$ $0.00192(n=11$, MSWD $=3.03)$ corresponding to a mineralisation age of $435_{-80}^{+75} \mathrm{Ma}(\mu=7.93)$. If samples of hematised amphibolite are excluded from the isochron calculation, the slope of the line is reduced to $0.05484 \pm$ $0.00260(n=7, \mathrm{MSWD}=3.53)$ and the age is $410_{-110}^{+100} \mathrm{Ma}$ $(\mu=7.95)$. Lead in pegmatite- and quartz vein-hosted pyrite samples from northern Dronning Louise Land define a much steeper ${ }^{207} \mathrm{~Pb} /{ }^{206} \mathrm{~Pb}$ isochron (Fig. 5) with a slope of $0.14298 \pm 0.00473(n=7$, MSWD $=1.03)$. The corresponding lead source age, assuming a Caledonian mineralisation age of $400 \mathrm{Ma}$, is $2070 \pm 60 \mathrm{Ma}(\mu=$ 7.91).

\section{Post-Jurassic fault breccias}

In Nordmarken and at Fladebugt in Germania Land (Fig. 1) pyrite-mineralised fault breccias are developed along subvertical fault planes that separate Palaeozoic Mesozoic sediments from the older gneisses. The exact age of mineralisation is not known, but Jurassic plant fossils in the down-faulted conglomeratic sandstones in Nordmarken give a maximum age of faulting here. Lead isotope data for the fault breccia-hosted pyrite mineral- 
Table 3. Lead isotope analyses for mineralised localities in the imbricate thrust zone, Dronning Louise Land

\begin{tabular}{|c|c|c|c|c|}
\hline Sample* & mineral & $\begin{array}{l}{ }^{206} \mathrm{~Pb} / \\
{ }^{204} \mathrm{~Pb}\end{array}$ & $\begin{array}{l}{ }^{207} \mathrm{~Pb} / \\
{ }^{204} \mathrm{~Pb}\end{array}$ & $\begin{array}{l}{ }^{208} \mathrm{~Pb} / \\
{ }^{201} \mathrm{~Pb}\end{array}$ \\
\hline
\end{tabular}

H. A. Jensen Bjerg, northern Dronning Louise Land $\begin{array}{lllll}035 \text { hematised mt-qzte py } & 39.973 & 16.619 & 46.013\end{array}$ $\begin{array}{lllll}036 \text { hematised mt-qzte py } & 19.745 & 15.550 & 38.226\end{array}$

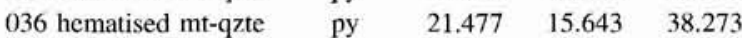

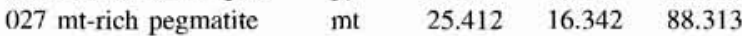
$\begin{array}{llllll}031 & \text { qz-py-cp vein } & \text { cp } & 18.506 & 15.575 & 38.530\end{array}$ $\begin{array}{lllll}040 \text { marble } & \text { py } & 18.660 & 15.624 & 37.620\end{array}$ $\begin{array}{lllll}047 \text { massive qz vein } & \text { py } & 25.150 & 16.541 & 47.885\end{array}$ $\begin{array}{lllll}048 \mathrm{qz} \text { vein } & \text { py } & 18.019 & 15.526 & 38.889\end{array}$ $\begin{array}{lllll}050 \mathrm{qz} \text { vein } & \text { py } & 20.233 & 15.850 & 40.789\end{array}$ $\begin{array}{lllll}050 \mathrm{qz} \text { vein } & \text { py } & 21.322 & 16.007 & 42.067\end{array}$ $\begin{array}{lllll}052 & \text { mt-rich pegmatite py } \quad 19.340 & 15.734 & 38.048\end{array}$

Eigil $S \phi$ area, western Dronning Louise Land

$\begin{array}{lllll}001 \text { hematised amph } & \mathrm{hm} & 17.253 & 15.385 & 39.228 \\ 001 \text { hematised amph } & \mathrm{hm} & 17.358 & 15.400 & 39.327 \\ 001 \text { hematised amph } & \mathrm{wr} & 17.592 & 15.451 & 39.735 \\ 002 \text { qz-hm vein in amph } & \mathrm{hm} & 17.172 & 15.382 & 38.924 \\ 007 \text { qz-hm vein in gneiss } & \mathrm{hm} & 18.667 & 15.482 & 40.620 \\ 008 \text { qz-hm vein in gneiss } & \mathrm{hm} & 24.406 & 15.831 & 44.421 \\ 011 \text { hematised pelite } & \mathrm{hm} & 38.913 & 16.626 & 39.880 \\ 012 \text { hematised mt-qzte } & \mathrm{hm} & 32.329 & 16.278 & 40.504\end{array}$

*GGU sample numbers prefixed 365 .

amph: amphibolite; cp: chalcopyrite; hm: hematite; mt: magnetite; py: pyrite; qz: quartz; qzte: quartzite; wr: whole-rock.

isation are listed in Table 4. Samples from Fladebugt and Nordmarken together define a ${ }^{207} \mathrm{~Pb} / 204 \mathrm{~Pb}-{ }^{206} \mathrm{~Pb} /{ }^{204} \mathrm{~Pb}$ linear array with a slope of $0.16184 \pm 0.01487(n=10$, MSWD $=1.33$ ) (Fig. 6). Using $t=0$ (recent mineralisation) in Equation 1 gives a maximum source age of $2475_{-160}^{+50} \mathrm{Ma}(\mu=7.92)$, i.e. Late Archaean to Early Proterozoic. Using a Tertiary mineralisation age (e.g. $t=$ $50 \mathrm{Ma}$ ) only reduces $T$ slightly to $2455_{-165}^{+150} \mathrm{Ma}$.

\section{Discussion and conclusions}

Secondary isochrons defined by data from sulphide and non-sulphide mineral occurrences describe evolution of lead during different intervals of time in the history of the rocks concerned. An isochron outlined by lead isotope ratios in sulphide minerals (where ${ }^{238} \mathrm{U} /{ }^{204} \mathrm{~Pb} \approx 0$ ) describes the evolution of the lead prior to the sulphide mineralisation, and in Equation 1, $T$ is therefore the age of the source of lead. An isochron defined by data for non-sulphide minerals (with high ${ }^{238} \mathrm{U}^{204} \mathrm{~Pb}$ ratios) describes lead evolution from the time $T$ of mineralisation until the present time. The indicated source or mineral- isation ages are only approximations, because the interpretation of secondary isochrons is based on assumptions whose validity cannot always be fully assessed, e.g.: initial homogeneity of lead isotope compositions in the source rocks; closed-system behaviour of source rocks or minerals until the time of mineralisation; age of mineralisation; non-evolution of lead in sulphide minerals.

When using an age of $400 \mathrm{Ma}$ for Caledonian sulphide mineralisation in Equation 1, assuming no further evolution of the lead since that time, the resulting lead source age is a minimum estimate. An estimate of the maximum age is obtained by using a mineralisation age of $t=0$ (tantamount to postulating continued evolution of lead in the sulphide minerals after mineralisation). For the rocks reviewed here, such maximum ages are about 200-300 Ma higher than the minimum ages stated.

Archaean $(\sim 3000 \mathrm{Ma})$ rocks in North-East Greenland were reported by Steiger et al. (1976) from studies on banded gneisses from the Danmarkshavn area (Fig. 1). New $\mathrm{Rb}-\mathrm{Sr}$ and $\mathrm{U}-\mathrm{Pb}$ isotopic dating results and $\mathrm{Sm}-\mathrm{Nd}$ model ages suggest that the rocks in large parts of the region are about $2000 \mathrm{Ma}$ old, and that reworking of Archaean material is traceable in some areas (Kalsbeek et

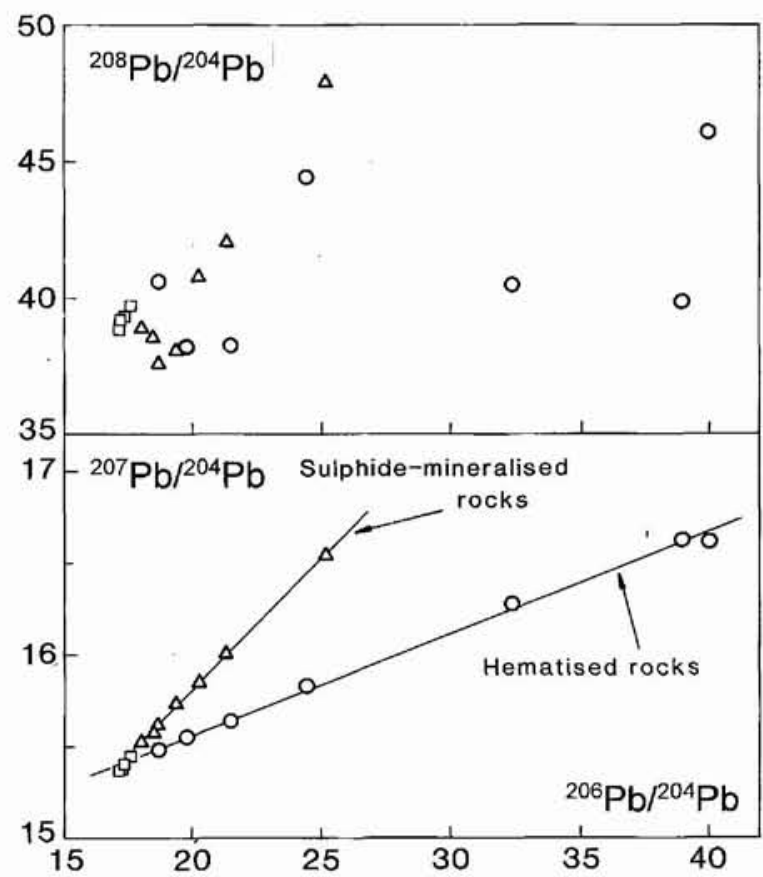

Fig. 5. Lead isotope diagrams for the imbricate thrust zone of Dronning Louise Land. Squares (hematised amphibolites) and circles (hematised magnetite placers) define ${ }^{207} \mathrm{~Pb} /{ }^{206} \mathrm{~Pb}$ isochron for Caledonian thrusts and hematisation; triangles (pyrite-mineralised pegmatites, quartz veins and marble) define ${ }^{207} \mathrm{~Pb} /{ }^{206} \mathrm{~Pb}$ isochron for source of lead in late Caledonian structures cutting the thrust sheets. 
al., 1993). The present lead isotope survey shows that these rocks appear to be the source of lead in mineralisations ranging from Lower Proterozoic to post-Jurassic in age. Further south in East Greenland, between latitudes $70^{\circ}-74^{\circ} 30^{\prime} \mathrm{N}$, indicated lead source ages for Caledonian mineralisations are Middle Proterozoic (Jensen, 1993) or Lower Proterozoic (S. M. Jensen, unpublished data). In the Kangerlussuaq region (about $68^{\circ} \mathrm{N}$ ) Archaean lead source ages are indicated for mineralisation associated with Tertiary magmatic activity (Jensen, 1993).

In North-East Greenland the highest apparent source ages for lead in mineralised rocks are found in pyrite in post-Jurassic fault breccias, and the lead appears to have been derived from the local basement gneisses.

Data points for highly radiogenic lead define isochrons for Caledonian deformation of rocks that contain lead with much higher source ages. The 'old' lead in the modified skarn on the islands in Dove Bugt is similar in composition to the lead in the Lower Proterozoic skarn in Rechnitzer Land. In the imbricate thrust zone in western Dronning Louise Land Caledonian metamorphic hematisation and influx of uranium was followed by intrusion of pegmatites and mobilisation of lead with a source age of about $2100 \mathrm{Ma}$. The source of the 'old' lead here is probably the gneisses that underlie the thrust sheets.

The shear zones and skarns in the Bessel Fjord region are Caledonian in age but have mobilised lead with a

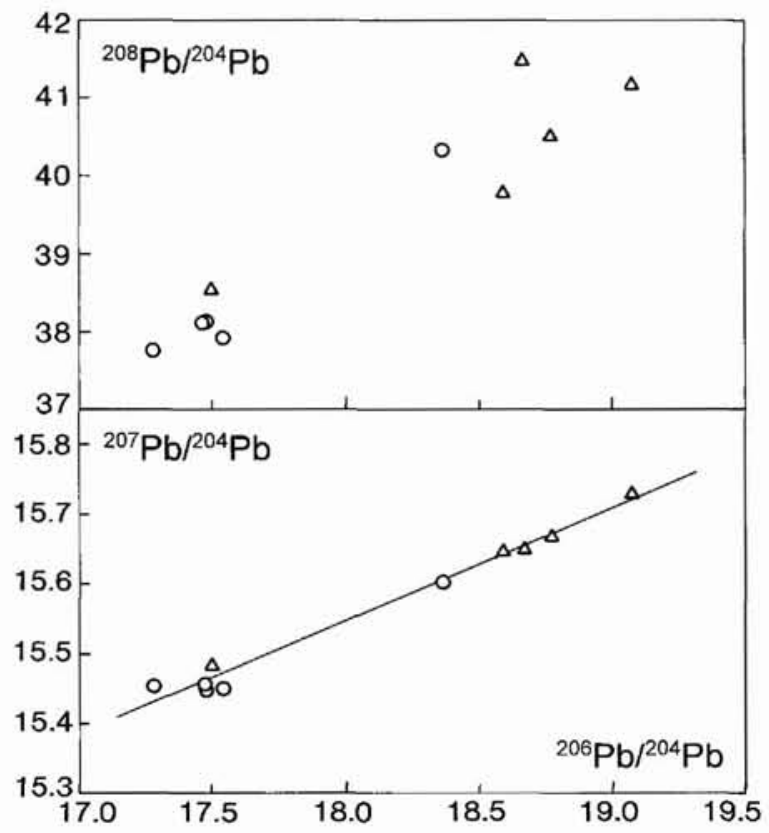

Fig. 6. Lead isotope diagrams for post-Jurassic fault breccias. Triangles (Nordmarken) and circles (Fladebugt) define ${ }^{207} \mathrm{~Pb} /{ }^{206} \mathrm{~Pb}$ isochron for source of mobilised lead, the local gneisses.
Table 4. Lead isotope analyses for pyritemineralised post-Jurassic fault breccias

\begin{tabular}{lcccc}
\hline Sample* & & ${ }^{206} \mathrm{~Pb} /$ & ${ }^{207} \mathrm{~Pb} /$ & ${ }^{200} \mathrm{~Pb} /$ \\
& mineral & ${ }^{204} \mathrm{~Pb}$ & ${ }^{204} \mathrm{~Pb}$ & ${ }^{204} \mathrm{~Pb}$ \\
\hline
\end{tabular}

\section{Nordmarken}

096 chd-cement. breccia 097 chd-cement. breccia $100 \mathrm{cc}$ vein/massive py 114 chd-cement. breccia 115 chd-cement. breccia

$\begin{array}{llll}\text { py } & 17.500 & 15.434 & 38.558 \\ \text { py } & 18.591 & 15.598 & 39.795 \\ \text { py } & 18.769 & 15.619 & 40.509 \\ \text { py } & 19.076 & 15.682 & 41.177 \\ \text { py } & 18.668 & 15.600 & 41.477\end{array}$

Fladebugt, Germania Land

$\begin{array}{lllll}077 \text { pegmatite breccia py } & 17.543 & 15.400 & 37.924\end{array}$

$\begin{array}{lllll}080 \text { breccia } & \text { py } & 17.280 & 15.404 & 37.766\end{array}$

$\begin{array}{lllll}084 \mathrm{breccia} / \mathrm{py} \text { veinlets } & \text { py } & 17.474 & 15.407 & 38.125\end{array}$

$\begin{array}{lllll}091 \text { breccia } & \text { py } & 17.480 & 15.399 & 38.128\end{array}$

$\begin{array}{lllll}092 \text { breccia } & \text { py } & 18.364 & 15.553 & 40.330\end{array}$

*GGU sample numbers prefixed 365 .

cc: calcite; chd: chalcedony; py: pyrite.

source age of 900-1000 Ma. The most likely source of the lead is the local host rocks of the Middle Proterozoic Smallefjord supracrustal sequence. Lead in mineralised country rocks to the Caledonian Storstrømmen shear zone has a similar source age, and may also have been derived from Middle or Late Proterozoic cover rocks. A model that invokes mobilisation of metals at deep crustal levels and funnelling of the metamorphic fluids through shear zones could explain the lead isotope signature of mylonitised rocks from the Storstrømmen shear zone as well as scattered small gold anomalies in stream sediments in eastern Dronning Louise Land (see Jensen \& Stendal, 1994).

Lead with source ages of 1700-2500 Ma (Rechnitzer Land, Nordmarken, Fladebugt and northern Dronning Louise Land) was mobilised from source rocks with uniform, relatively low $\mu$ values (7.9-8.0). For the lead sources with ages of about $900-1000 \mathrm{Ma}$, the $\mu$ values are slightly higher (8.0-8.1), and for Caledonian radiogenic lead the $\mu$ values are 8.1-8.3. Depletion of uranium relative to thorium in whole-rock systems is characteristic of high-grade metamorphism (e.g. Gray \& Oversby, 1972) and could explain the relatively low first-stage $\mu$ values for the Lower Proterozoic gneisses. Several highgrade metamorphic terrains have been recognised in the region studied during GGU's geological mapping in 1989 and 1990 (e.g. Friderichsen et al., 1991; Chadwick \& Friend, 1991).

Acknowledgements. The Faculty of Natural Sciences, University of Aarhus is thanked for funding a Ph.D. study, and J. E. Wright, Department of Geology and Geophysics, Rice University, Houston, 
Texas, for providing facilities for lead isotope analyses. I thank $\mathrm{H}$. Stendal for discussions during and after field work, and F. Kalsbeek for helpful comments to the first draft of this paper. The analytical programme was financed by the Danish Natural Science Research Council and the Danish Research Academy.

\section{References}

Chadwick, B. \& Friend, C. R. L. 1991: The high-grade gneisses in the south-west of Dove Bugt: an old gneiss complex in a deep part of the Caledonides of North-East Greenland. Rapp. Gronlands geol. Unders. 152, 103-111.

Chadwick, B., Friend, C. R. L. \& Higgins, A. K. 1990: The crystalline rocks of western and southern Dove Bugt, NorthEast Greenland. Rapp. Gronlands geol. Unders. 148, 127132.

Chadwick, B., Friend, C. R. L., George, M. C. \& Perkins, W. T. 1993: A new occurrence of musgravite, a rare beryllium oxide, in the Caledonides of North-East Greenland. Mineralog. Mag. 57, 121-129.

Faure, G. 1986: Principles of isotope geology (second edition), 589 pp. New York: John Wiley \& Sons.

Friderichsen, J. D., Gilotti, J. A., Henriksen, N., Higgins, A. K., Hull, J. M., Jepsen, H. F. \& Kalsbeek, F. 1991: The crystalline rocks of Germania Land, Nordmarken and adjacent areas, North-East Greenland. Rapp. Gronlands geol. Unders. 152 , 85-94.

Gray, C. M. \& Oversby, V. M. 1972: The behaviour of lead isotopes during granulite facies metamorphism. Geochim. Cosmochim. Acta 36, 939-952.

Jensen, S. M. 1993: Lead isotope studies on mineral showings and ore deposits in East Greenland. Rapp. Gronlands geol. Unders. 159, 101-108.

Jensen, S. M. \& Stendal, H. 1994: Reconnaissance for mineral occurrences in North-East Greenland $\left(76^{\circ}-78^{\circ} \mathrm{N}\right)$. Rapp. Gronlands geol. Unders. 162 (this volume).

Kalsbeek, F., Nutman, A. P. \& Taylor, P. N. 1993: Palaeoproterozoic basement province in the Caledonian fold belt of North-East Greenland. Precambrian Res. 63, 163-178.

Kanasewich, E. R. 1968: The interpretation of lead isotopes and their geological significance. In Hamilton, E. I. \& Farquhar, R. M. (ed.) Radiometric dating for geologists, 147-223. New York: Interscience Publishers.

Steiger, R. H. \& Jäger, E. 1977: Subcommission on geochronology: convention on the use of decay constants in geo- and cosmochronology. Earth Planet. Sci. Lett. 36, 359-362.

Steiger, R. H., Harnik-Šoptrajanova, G., Zimmermann, E. \& Henriksen, N. 1976: Isotopic age and metamorphic history of the banded gneiss at Danmarkshavn, East Greenland. Contr. Miner. Petrol. 57, 1-24.

Tatsumoto, M., Knight, R. J. \& Allègre, C. J. 1973: Time differences in the formation of meteorites as determined from the ratio of lead-207 to lead-206. Science 180, 1279-1283.

Todt, W., Cliff, R. A., Hanser, A. \& Hoffmann, A. W. 1984: ${ }^{202} \mathrm{~Pb}+{ }^{205} \mathrm{~Pb}$ double spike for lead isotopic analyses. Terra Cognita 4(2), 209 only.

York, D. 1969: Least squares fitting of a straight line with correlated errors. Earth Planet. Sci. Lett. 5, 320-324. 